\title{
ASSESSMENT OF HISTORICAL AERIAL PHOTOGRAPHY AS INITIAL SCREENING TOOL TO IDENTIFY AREAS AT POSSIBLE RISK TO SINKHOLE DEVELOPMENT
}

Clint Kromhout

Florida Geological Survey, 3000 Commonwealth Boulevard, Suite \#1, Tallahassee, Florida 32303, USA,

Clint.Kromhout@dep.state.fl.us

Michael C. Alfieri

Water Resource Associates, LLC, 4260 West Linebaugh Avenue, Tampa, Florida 33624, USA,

Malfieri@wraengineering.com

\begin{abstract}
Use of historical aerial photography to perform desktop site assessments to mitigate cover-collapse sinkhole risk is not a new concept in the geoscientific arena. Unfortunately, it has not been a routine part of the decision matrix for land-use planning and development. This paper demonstrates the importance of historical aerial photography analysis as a preliminary tool to identify site-specific sinkhole risk. Three case studies are presented to underscore this observation. In sinkholeprone regions in parts of Florida and many other states across the county, infrastructure siting and other landuse planning activities would be well-served to include this type of analysis.
\end{abstract}

\section{Introduction}

Littlefield et al. (1984) demonstrated that sinkholes tend to preferentially occur along fracture traces and at fracture-trace intersections. The use of historical aerial photography to identify photolineaments and, after ground-truthing, fracture traces is not a new concept. The Florida Geological Survey's Special Publication No. 57 recommends the use of historical aerial photography as an integral part of the desktop evaluations to assess potential subsidence (Schmidt 2005). In 2015, Florida Administrative Code (Rule 62-701.410, F.A.C.) required assessment of historical aerial photography to identify potential karst hazards for proposed landfill sites.

In areas where regolith thinly covers limestone, or is bare, there is a higher correlation between photo-interpreted features and fractures. This degree of correlation does not exist in covered karst terrains, such as Florida, which necessitates photolinear verification to minimize risk of harm or failure. Schmidt (2005) indicates semicircular depressions, wetlands, and other features observed on aerial photographs or other remotely sensed images may represent sinkholes or other karst features, but not in every case.
This paper documents results of historical aerial photographic review of three recent catastrophic sinkholes that were headline news in Florida, and in the international press, to determine if historical aerial photography might have provided clues to these future catastrophic events.

\section{July 14, 2017: Ocean Pines Drive, Land O' Lakes, Florida Sinkhole description and metrics}

The Ocean Pines Drive sinkhole (Site 1) is a large cover-collapse sinkhole which formed abruptly the morning of July 14, 2017 (Figures 1 and 2). Two homes were destroyed by the collapse and eight others were condemned. No people or pets were injured. One of the two homes had been previously "remediated" for sinkhole activity with pin piles. The sinkhole dimensions were: length 50 meters (164 feet), width 42 meters (137.8 feet), and depth 12 meters (40 feet).

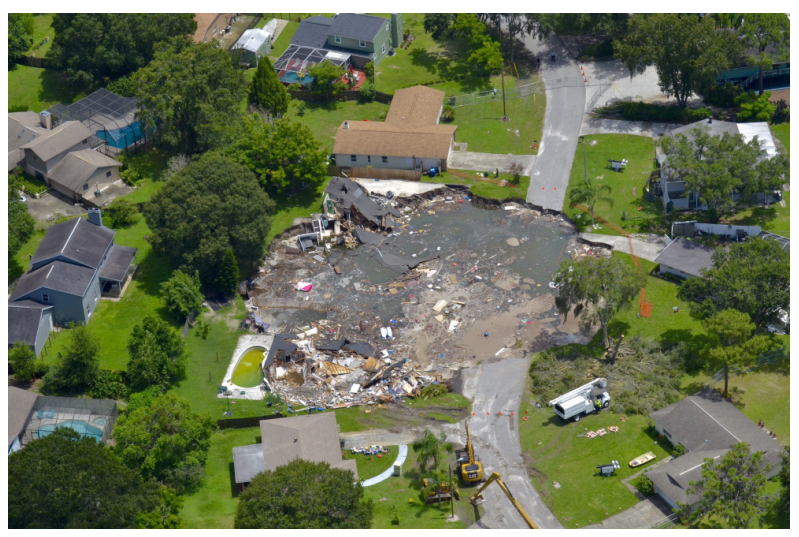

Figure 1. Ocean Pines Drive sinkhole, bottom of photograph is north (WFLA NBC 8, 2017) 


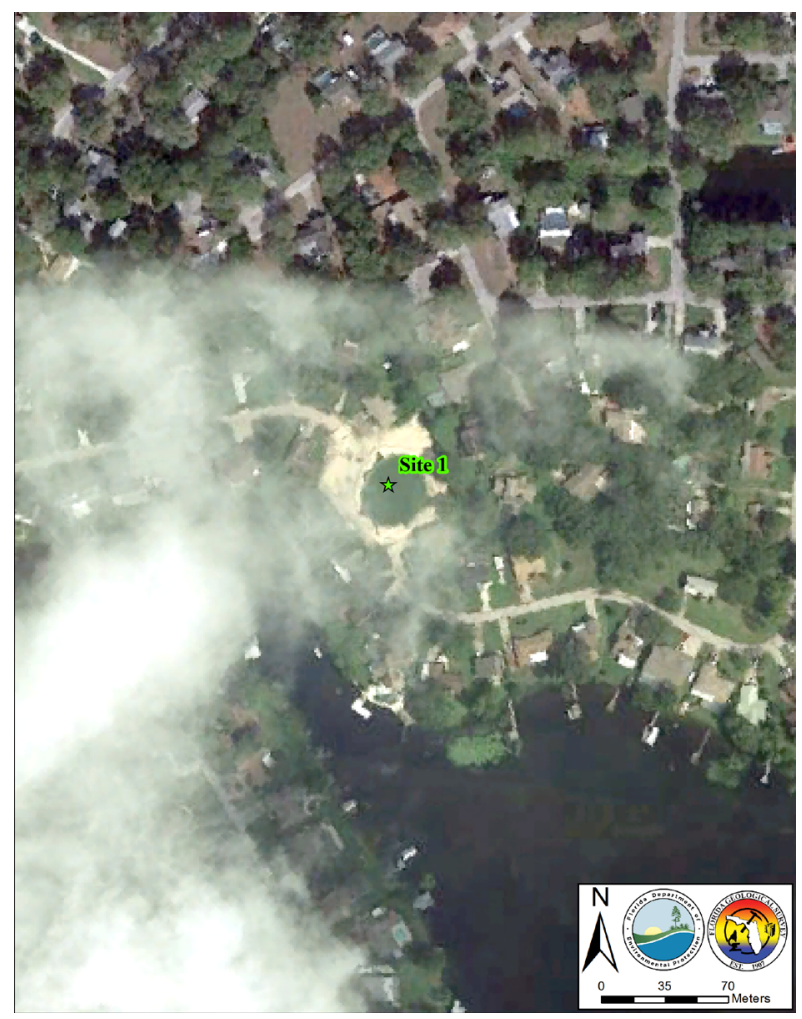

Figure 2. Site 1 location on 2017 aerial imagery (Google Earth, 2017)

\section{Location map and historical aerials}

Site 1 is located in Land O' Lakes, Florida, approximately $28 \mathrm{~km}$ (17.4 mi) north of Tampa, Florida (Figure 3). Land O' Lakes received its name from the hundreds of karst lakes in the region. The lakes gain their lobed appearance from millions of years of sinkhole development.

To assess risk to potential sinkhole formation at Site 1 using historical aerial photography, photos from 1938, 1957, 1965 and 1974 (Figures 4, 5, 6, and 7) were downloaded and georeferenced into a geographic information system (GIS). The advantage of analyzing photos from multiple years allows one to see the area of interest in predevelopment (Figure 4 and 5) and during development (Figure 6 and 7), at different water table elevations, historical drainage patterns, and most importantly, the presence of pre-existing karst features.

\section{General Geologic Setting}

The sinkhole is located in the Land O' Lakes Karst Plain province (Green et al., 2012a, Green et al., 2012b, Williams et al., in preparation) which is typified by a thin veneer of undifferentiated Quaternary sediments comprised of clayey sands, sandy clays, and clay sitting directly on top of Oligocene Tampa Member limestone of the Arcadia Formation of the Hawthorn Group. Nearby

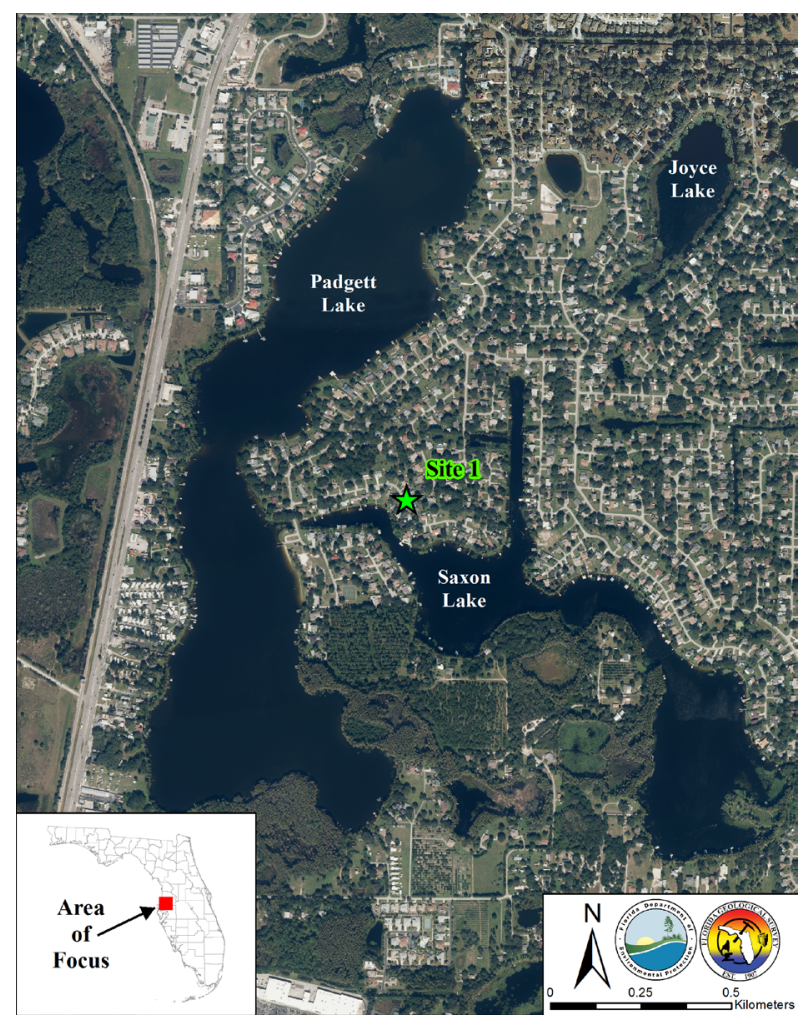

Figure 3. Site 1 location on 2014 aerial photography (FDEP LABINS, 2017)

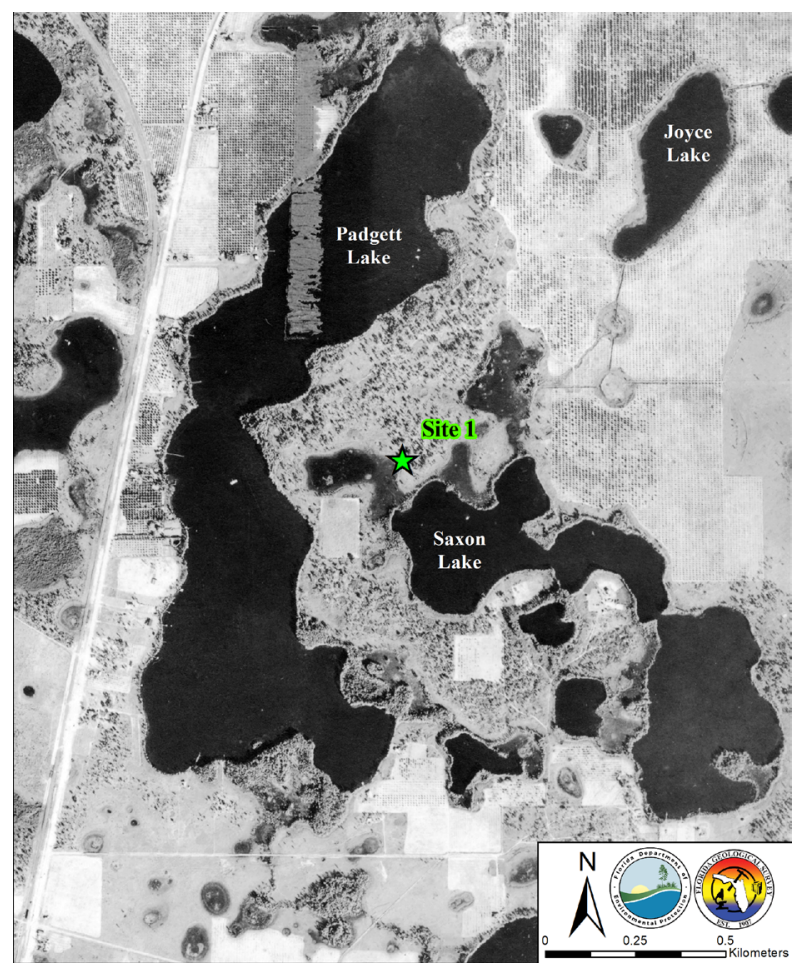

Figure 4. Site 1 location on 1938 USDA aerial photography (University of Florida, 2017) 


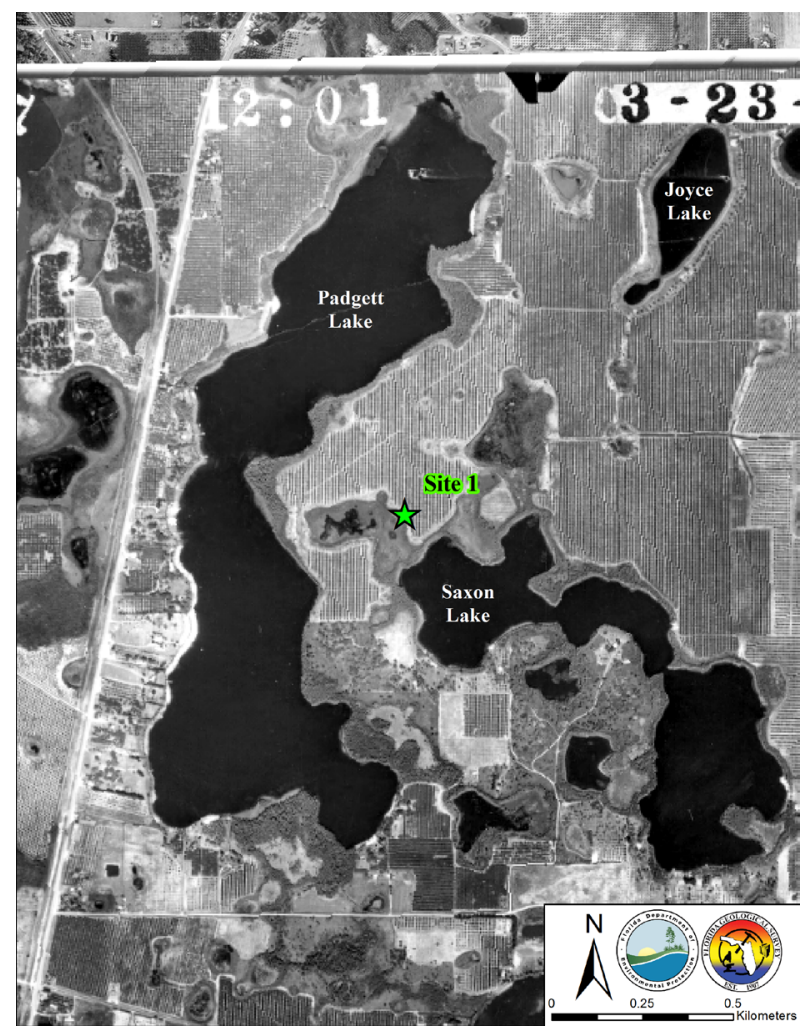

Figure 5. Site 1 location on 1957 USDA aerial photography (University of Florida, 2017)

lithologic boreholes indicate limestone is encountered approximately 15.2 meters (50 feet) below land surface (Green et al., 2012a).

\section{Discussion of Observations}

When comparing Figures 4 and 5 to Figures 6 and 7, the most immediate difference observed in the images is the shape of Saxon Lake. On the north and northwestern reaches of the lake, significant dredge and fill activity occurred beginning sometime between 1957 and 1965 (Figure 5 and 6). In Figures 4 and 5, Site 1 is located just inside a polje, with multiple circular sinkhole features visible, that were subsequently dredged and filled by 1965 (Figure 6). A photolinear of sinkholes arranged in a line oriented north-northeast starting at the bottom left of Figure 4 is nearly parallel to the long axis of Padgett Lake and passes through Saxon Lake up to Joyce Lake. By 1974 (Figure 7) the dredge and fill process is complete, Saxon Lake has been canaled to connect with Padgett Lake, and homes are beginning to be built on the newly created lake-front lands. In addition to an established history of sinkholes, the dredged fill material, where housing was later built, likely poses a risk to the general sediment stability due to compaction of former lake bed sediments.

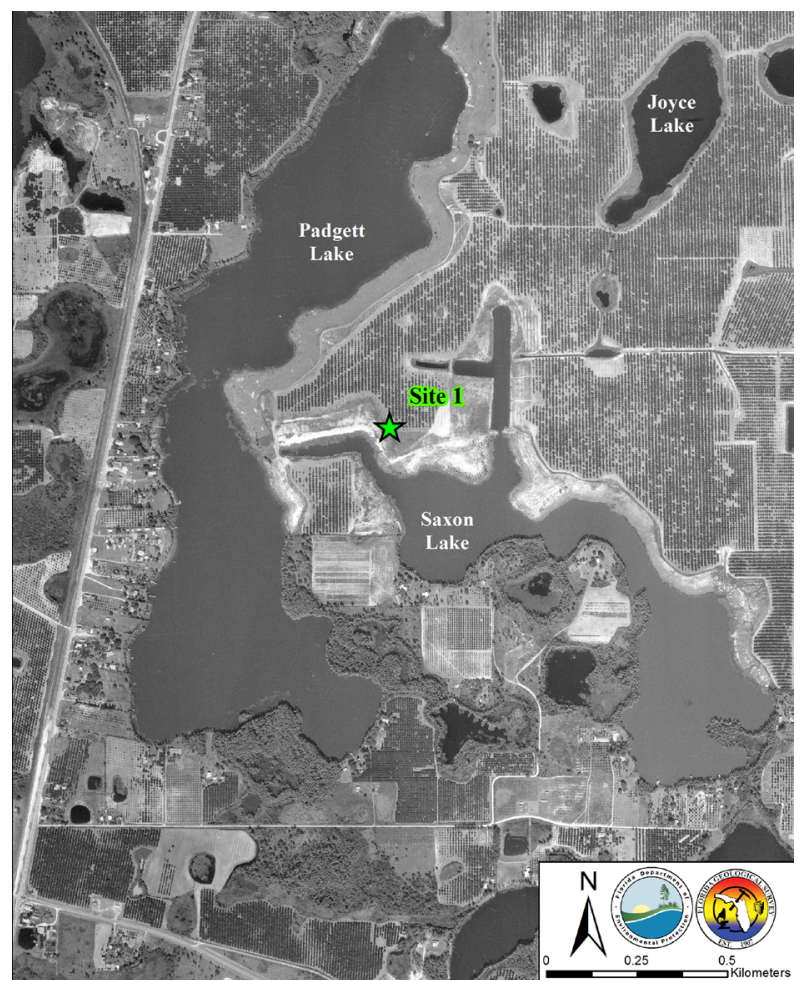

Figure 6. Site 1 location on 1965 FDOT aerial photography.

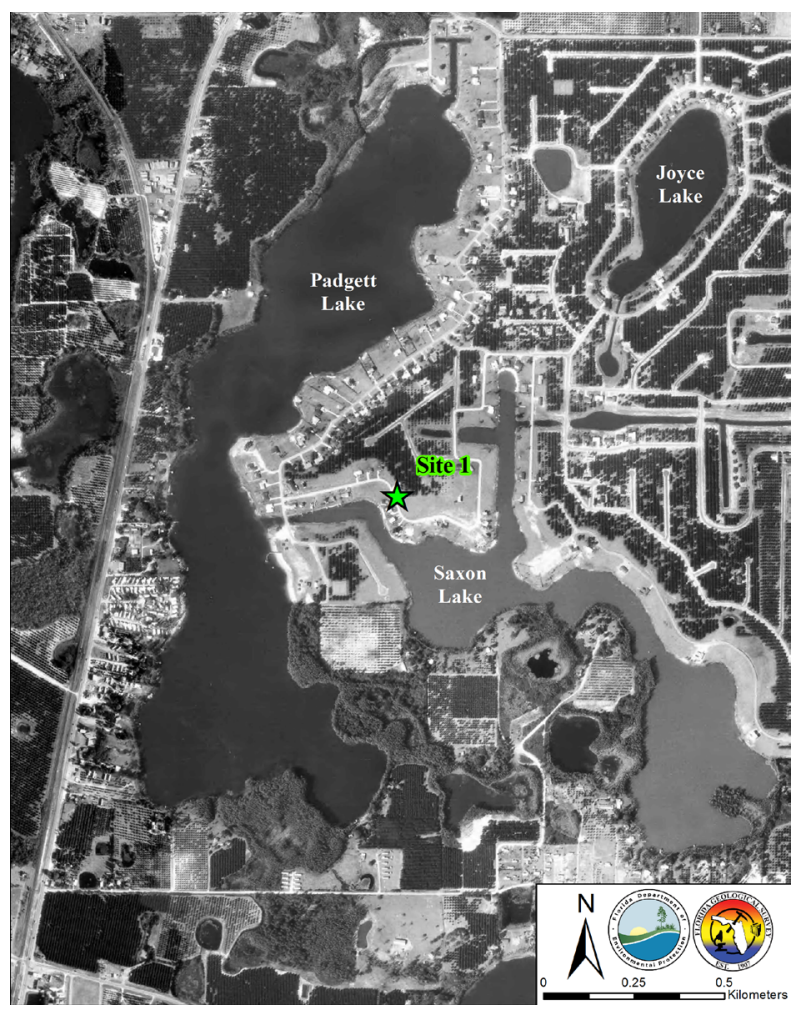

Figure 7. Site 1 location on 1974 USDA aerial photography (University of Florida, 2017) 


\section{December 18, 2004: Howland \\ Boulevard, Deltona, Florida Sinkhole description and metrics}

The Howland Boulevard sinkhole (Site 2) is a large covercollapse sinkhole which formed abruptly on Saturday December 18, 2004 (Figure 8). As a precaution, twenty homes in the vicinity of the sinkhole were evacuated. The sinkhole formed when workers were attempting to compact, using pumped concrete, the soft sediment below the road's base, which had partially subsided shortly after the road was constructed. The road leading south from the sinkhole is an entrance to a local high school. The sinkhole eventually grew to an estimated diameter of 68.5 meters (225 feet) and a depth of 15.2 meters (50 feet).

\section{General Geologic Setting}

Site 2 is located in the DeLand Ridge province which is characterized by rolling karst hills with closed basin lakes and sand dune fields (Williams et al., in preparation). The ridge is underlain by approximately 23 meters (75 feet) of quartz sand with minor amounts of organics overlying limestone and dolostone of the middle Eocene Avon Park Formation.

\section{Location map and historical aerials}

Site 2 is located approximately $36 \mathrm{~km}$ (22.5 mi) southwest of Daytona Beach, Florida (Figure 9). To assess Site 2's risk to potential sinkhole formation using historical aerial photography, photos from 1943 and 1973 (Figures 10 and 11) were downloaded and georeferenced into a GIS.

\section{Discussion of Observations}

Immediately visible in the 1943 photograph (Figure 10) adjacent to Site 2 is a large circular stand of trees

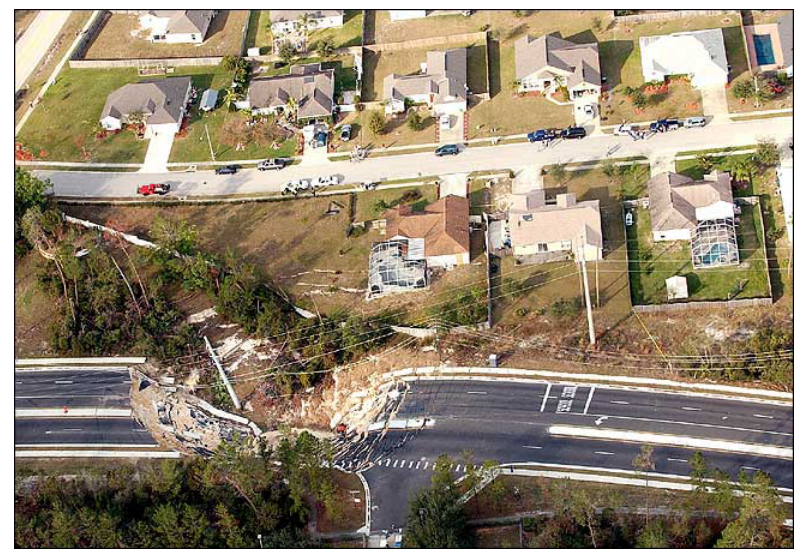

Figure 8. Site 2 sinkhole, top of photograph is north (New York Times, 2004)

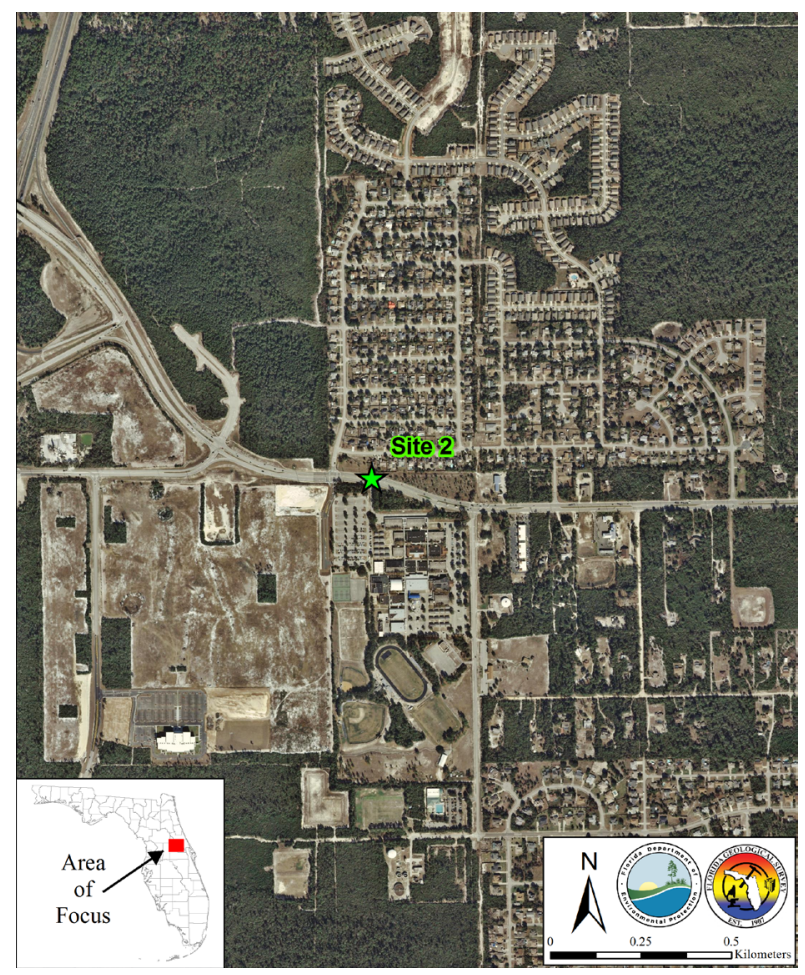

Figure 9. Site 2 location on 2012 aerial photography (FDEP LABINS, 2017)

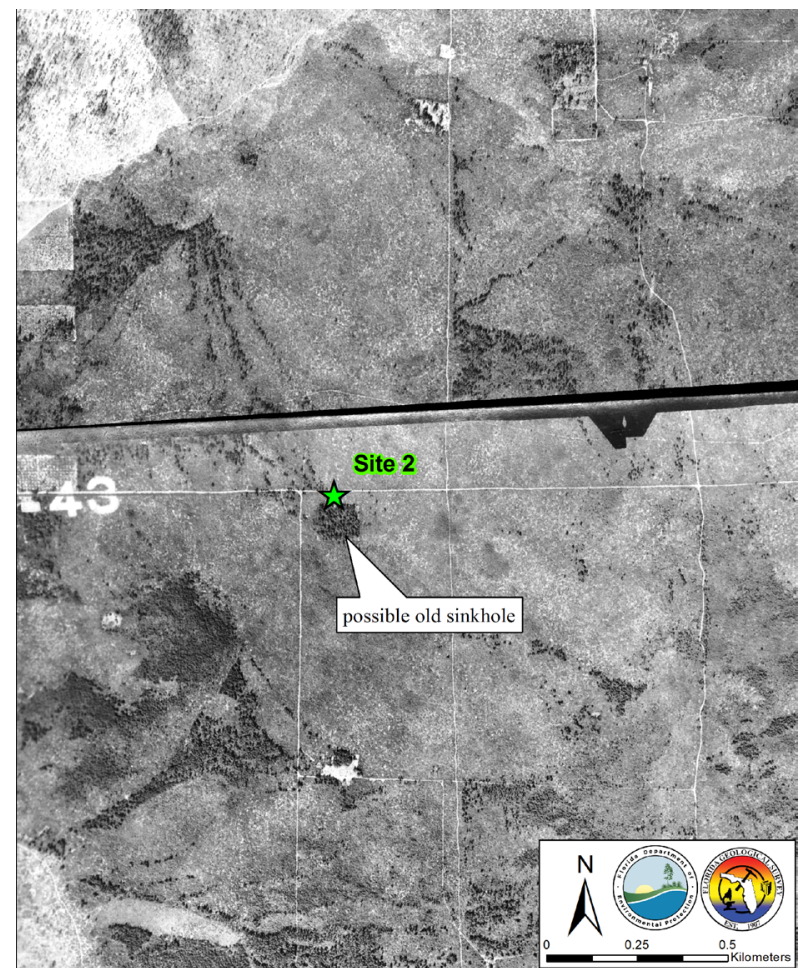

Figure 10. Site 2 sinkhole location on 1943 USDA aerial photography (University of Florida, 2017) 


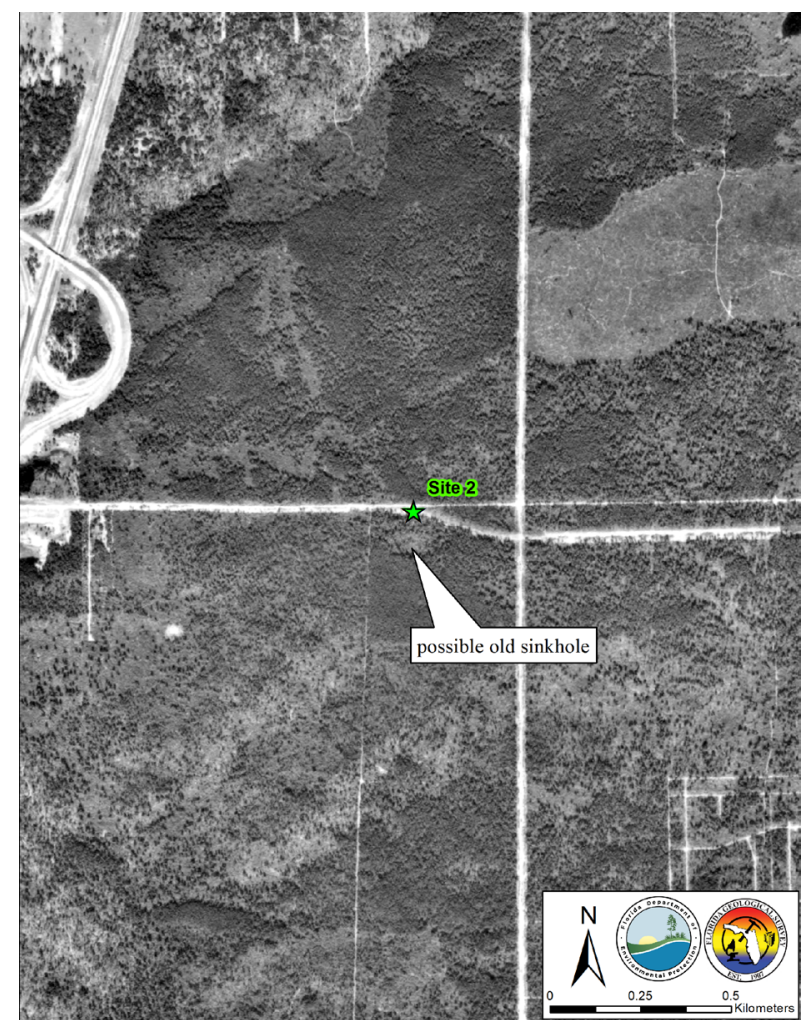

Figure 11. Site 2 sinkhole location on 1973 USDA aerial photography (University of Florida, 2017)

suggesting the presence of a historical sinkhole. The stand of trees exhibits a circular shape. Throughout Florida and other karst regions where sinkholes are common, tree clusters in a circular shape are a common occurrence and are generally related to karst. Furthermore, northwestsoutheast soil-tone and vegetation photolinears cut through and are adjacent to the site (Figure 10). In Figure 11, the circular shape visible, but the vegetation has changed.

\section{June 10, 20172701 SW College Road and September 11, 20173410 SW College Road, Ocala, Florida Sinkhole description and metrics}

Separated by approximately $1.5 \mathrm{~km}(0.9 \mathrm{mi})$ and 3 months, sinkholes opened at two fast-food restaurants on SW College Road in Ocala, Florida (Figure 12). Both sinkholes made headlines due to the partial collapse of the parking lots that damaged two vehicles. The June 10, 2017 sinkhole at $2701 \mathrm{SW}$ College Road, herein referred to as Site $3 \mathrm{~A}$, was approximately 7.6 meters ( $25 \mathrm{feet}$ ) in width and depth (Figure 13). The partial collapse of the parking lot damaged a Kia Optima. The September 11, 2017 sinkhole at 3410 SW College Road, herein referred to as Site $3 \mathrm{~B}$, was approximately $3 \mathrm{~m}$ in width, based

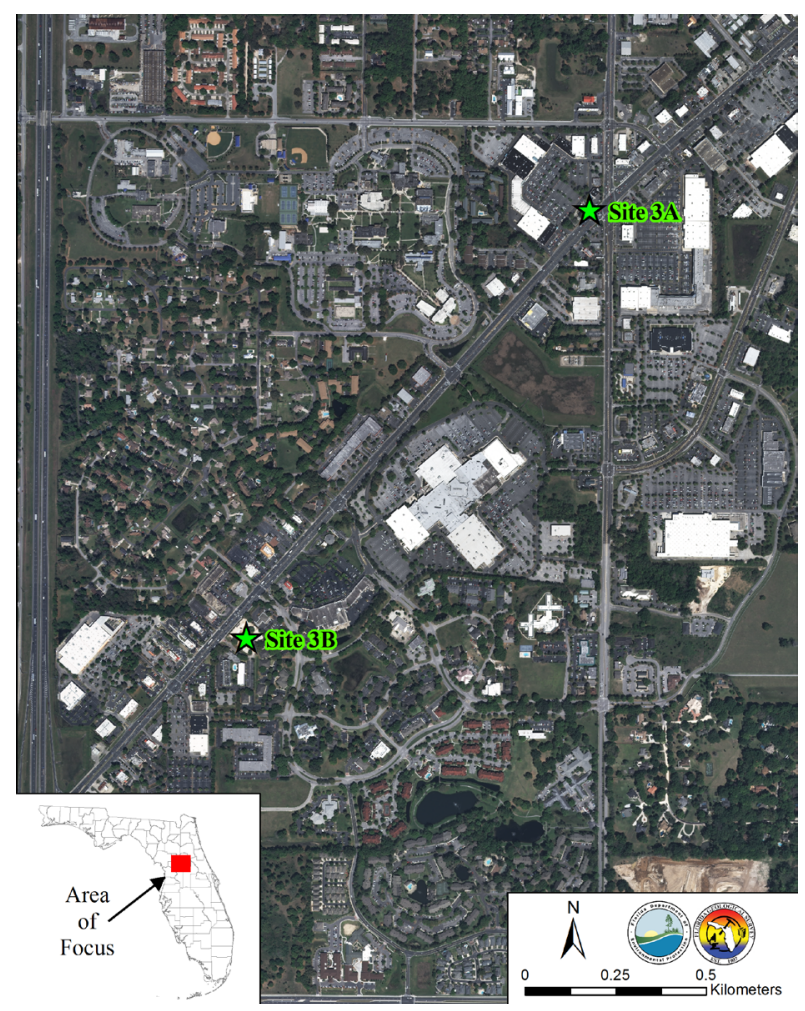

Figure 12. Site $3 A$ and $3 B$ locations on 2014 aerial photography (FDEP LABINS, 2017).

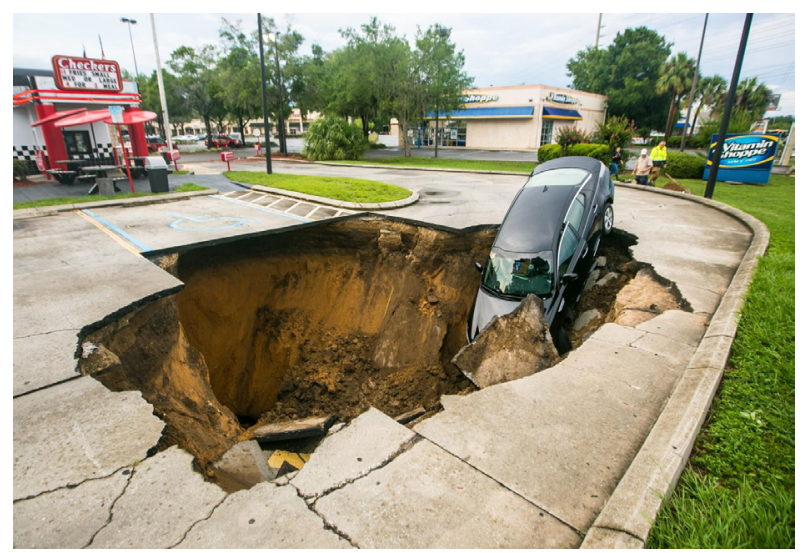

Figure 13. Site $3 \mathrm{~A}$ sinkhole, top left of photograph is north (Miller, 2017).

on video review, however, the depth was not reported (Figure 14). The partial collapse of the parking lot damaged a Toyota Tundra.

\section{General Geologic Setting}

Both sites reside in the mature karst topography of the Ocala Karst Hills province (Williams et al., in preparation) and are geologically similar. The underlying strata at both sites are comprised of a thin layer of undifferentiated sediments containing primarily quartz 


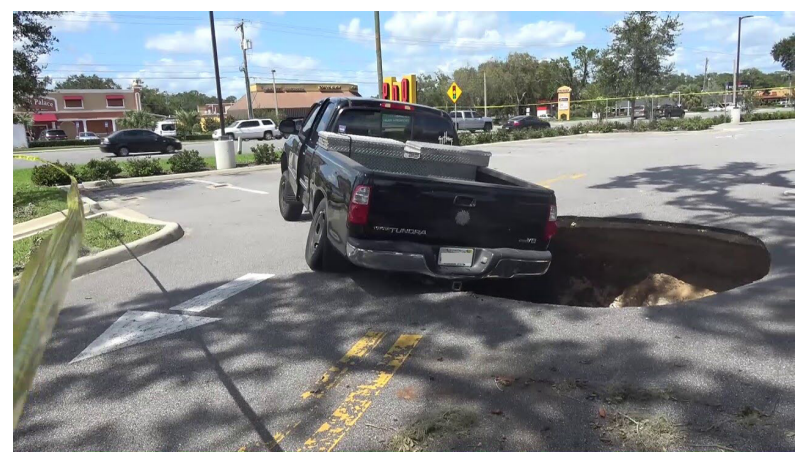

Figure 14. Site $3 B$ sinkhole, top left of photograph is north (Kenyon, 2017).

sand with variable admixtures of clay and organics with minor chert, overlying the Eocene Ocala Limestone. The limestone occurs within less than 6 meters (20 feet) from land surface.

\section{Location map and historical aerials}

Sites $3 \mathrm{~A}$ and $3 \mathrm{~B}$ are located near the northeast offramp of I-75 and SW College Road in Ocala, Florida. To assess the risk of sinkhole formation at Site $3 \mathrm{~A}$ and 3B using historical aerial photography, USDA and FDOT historical aerial photographs from 1956 and 1983 (Figures 15 and 16) were downloaded (FDEP LABINS, 2017) and georeferenced into a GIS.

\section{Discussion of observations}

Unlike the prior case studies presented in this paper, these sites are specifically presented to demonstrate that the review of historical aerial photography is only a screening tool and should never be considered a means to derive definitive evidence for sinkhole formation. The historical aerial photographs reviewed provided evidence of proximal karst features including: photolineaments, closed topographic depressions (CTDs), potentially related to coalescing features; airfilled and water-filled cave systems; and swallets (Figure 17). This demonstrates a relatively decent correlation of observed features in the aerial photography and field identified karst features. However, none of these karst features are identified at either site locations. Based on the aerial photography reviewed, neither site had readily identifiable changes in soil tones or identified photolineaments (individual or intersecting). Site 3A does align with a linear of CTDs (Figure 17); however, those CTDs are not interpretable from the photos. If a review of historic aerial photography by qualified professionals had been conducted prior to construction at either of these sites they would more than likely have yielded similar results as this current evaluation, but the identification of the near-by karst features would suggest the need for additional screening using geophysical and/or geotechnical subsurface testing, such as, but

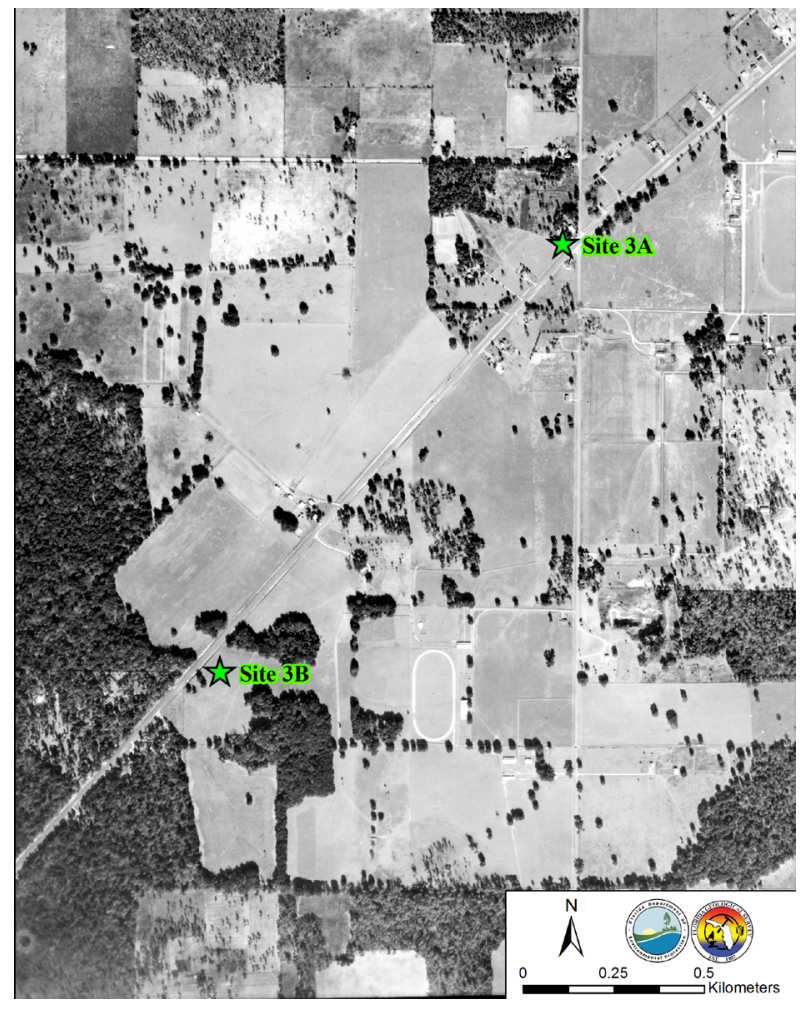

Figure 15. January 11, 1956 USDA aerial photography (University of Florida, 2017).

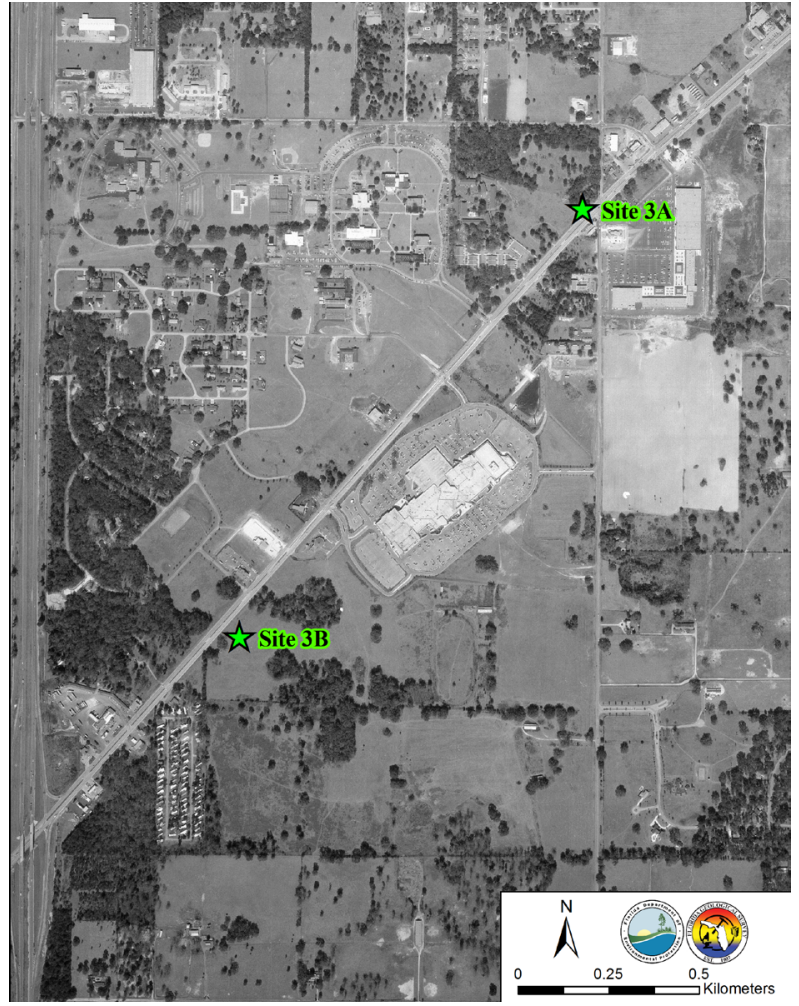

Figure 16. March 2, 1983 FDOT aerial photography. 


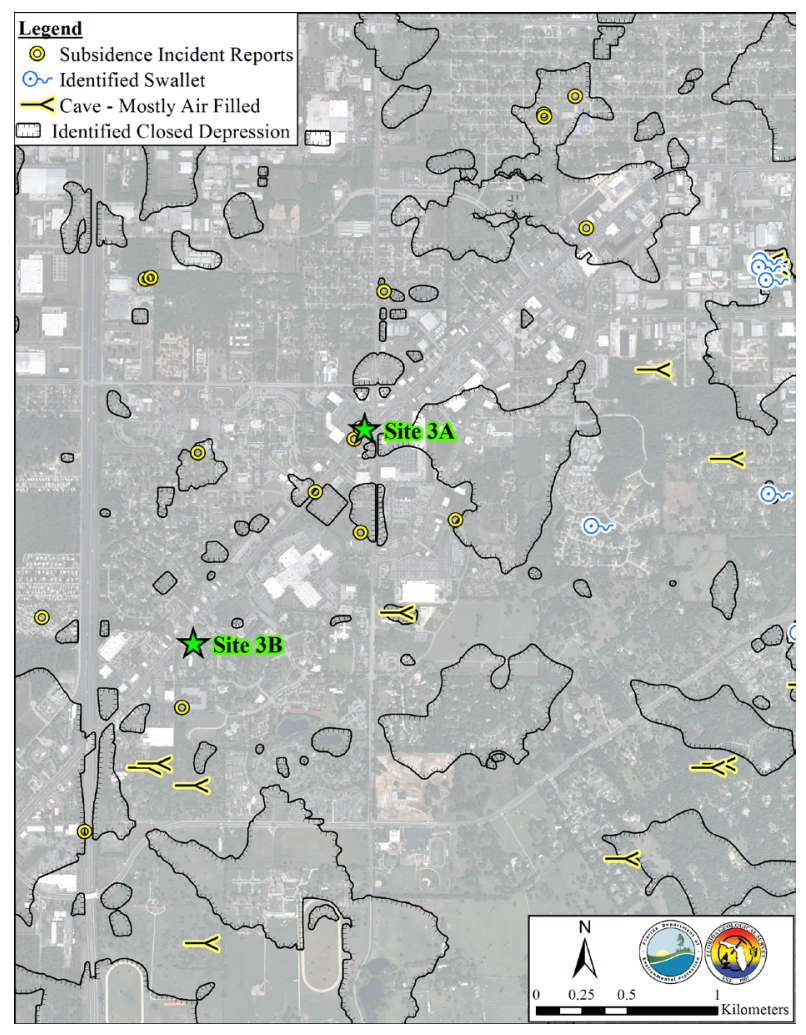

Figure 17. Karst related features proximity to Site 3A and 3B on 2014 aerial photography.

not limited to: ground penetrating radar (GPR), multielectrode electrical resistivity (MER), multi-channel analysis of sub-surface waves (MASW), standard penetration test (SPT) borings, or cone penetrometer test (CPT) soundings, prior to construction to evaluate the potential for sinkhole formation at the sites.

\section{Conclusions}

Sinkholes may form catastrophically and instantaneously, or form over geologic time. At present, the specific timing and location of sinkholes are largely difficult to predict. The case studies presented herein demonstrate the value of historical aerial photography to assess sinkhole risk prior to development. Had a requirement been in place, prior to development, the loss of property and potential endangerment to human welfare potentially could have been avoided.

Greater consideration should be given to use of this assessment tool. In fact, outcomes of such assessments could guide improved engineering requirements, landuse planning, and development. This type of screening, however, is by no means definitive. Additional screening or subsurface testing should also be completed prior to determining if a site is susceptible to sinkhole formation.

\section{References}

Arthur JD, Fischler C, Kromhout C, Clayton J, Kelley M, Lee RA, Li L, O'Sullivan M, Green R, Werner C. 2008. Hydrogeologic Framework of the Southwest Florida Water Management District. Florida Geological Survey Bulletin 68.

Cichon, J., in press Potentiometric surface map of the Upper Floridan aquifer, September 2016: Florida Geological Survey Map Series, scale 1:900,000, 1 sheet, (in press).

Fla. Admin. Code. 62-701.410 (2015)

Florida Department of Transportation. 1965. Aerial photographs of Hillsborough County HIL027706-33.

Florida Department of Transportation. 1973. Aerial photographs of Marion County PD1432-12-14.

Florida Department of Transportation. 1983. Aerial photographs of Marion County PD2939-12-15.

Florida Department of Environmental Protection Land Boundary Information System. 2012. High resolution images.

Florida Department of Environmental Protection Land Boundary Information System. 2014. Highresolution images.

Google Earth v 7.1.7.2606 (2017). Land O’ Lakes, Florida. $28.203482^{\circ} \mathrm{E},-82.455437^{\circ} \mathrm{W}$, Eye alt 2942 feet. SPOT IMAGE 2017: http://www.earth. google.com (accessed September 2017).

Kenyon, D., 2017, Sinkhole at PDQ restaurant on SR 200 Ocala FL: https://www.youtube. com/watch? $\mathrm{v}=$ cquuFKm5FWw (accessed on September 2017).

Littlefield JR, Culbreth MA, Upchurch SB, and Stewart MT. 1984. Relationship of modern sinkhole development to large-scale photolinear features. In: B.F. Beck, editor. Sinkholes: Their Geology, Engineering \& Environmental Impact, Rotterdam, B.A. Balkema.

Miller, A.L., 2017, Sinkhole, flooding after torrential rains on SR 200: http:/www.ocala.com/ news/20170610/sinkhole-flooding-after-torrentialrains-on-sr-200 (accessed September 2017).

Mueller, P., 2017, 2 more Land O' Lakes homes condemned after massive sinkhole grows: http:// wfla.com/2017/08/05/authorities-to-give-updateon-changes-at-massive-land-o-lakes-sinkhole/ (accessed September 2017).

New York Times, 2004, Photo: Florida's largest sinkhole in decades opened along Howland Boulevard in Deltona days before Christmas: http://www.nytimes.com/imagepages/2005/01/01/ national/01deltonaCA01 ready.html

Schmidt, W. 2005. Geological and geotechnical investigation procedures for evaluation of the 
causes of subsidence damage in Florida. Florida Bureau of Geology Special Publication No. 57.

University of Florida. 2017. Aerial Photography:

Florida http://www.uflib.ufl.edu/maps/

U.S. Department of Agriculture. 1938. Aerial

photographs of Hillsborough County - Flight 1.

U.S. Department of Agriculture. 1956. Aerial photographs of Marion County - Flight 1R.

U.S. Department of Agriculture. 1957. Aerial photographs of Hillsborough County - Flight 4T.

U.S. Department of Agriculture. 1943. Aerial photographs of Volusia County - Flight 4C

U.S. Department of Agriculture. 1973. Aerial photographs of Volusia County - Flight 173.

U.S. Department of Agriculture. 1974. Aerial photographs of Pasco County - Flight 474.

Williams, C.P., Scott, T.M., Upchurch S.B., Means, G.H., (in preparation) Geomorphic map of Florida: Florida Geological Survey. 